\title{
PROTECTIVE EFFECT OF AQUEOUS EXTRACT OF LEAVES OF MURRAYA KOENIGII, AGAINST ALUMINUM CHLORIDE-INDUCED OXIDATIVE STRESS IN RAT LIVER AND KIDNEY
}

\author{
MAHESWARI REDDY B ${ }^{1 *}$, DHANAPAL CK ${ }^{2}$, LAKSHMI BVS ${ }^{1}$ \\ ${ }^{1}$ Department of Pharmacology, Malla Reddy College of Pharmacy, Secunderabad, Hyderabad, Telangana, India. ${ }^{2}$ Department of Pharmacy, \\ Annamalai University, Chidambaram, Tamil Nadu, India. Email: mahi.unaj@gmail.com
}

Received: 09 March 2020, Revised and Accepted: 10 April 2020

\section{ABSTRACT}

Objective: The aim of the current study was to investigate the hepatoprotective, nephroprotective, and cholesterol-lowering activity of aqueous extract of Murraya koenigii (MK) leaves against $\mathrm{AlCl}_{3}$-induced oxidative stress in rats.

Methods: Wistar albino rats were distributed into six groups (6 each). Group I (control), and Group II administered with distilled water, and aluminum chloride $\left(\mathrm{AlCl}_{3}\right),(40 \mathrm{mg} / \mathrm{kg}$ body weight [b.w], oral), respectively. Group III rats were treated with standard Vitamin E (100 mg/kg b.w, p.o) and $\mathrm{AlCl}_{3}$ (40 mg/kg b.w, oral). Group IV, V, and VI received aqueous extract of leaves of Murraya koenigii (AEMK) (100 mg/kg b.w, peroral [p.o], $200 \mathrm{mg} / \mathrm{kg}$ b.w, p.o, and $400 \mathrm{mg} / \mathrm{kg}$ b.w, p.o), respectively, for a period of 35 days.

Results: Histopathological examination was observed deformities in hepatic and renal tissues due to aluminum exposure which augment the aforementioned results. Coadministration of AEMK along with Al significantly restored the serum biomarkers to their near-normal levels and has the ability to overcome Al-induced oxidative stress, manifested by a significant reduction in hepatic and renal malondialdehyde level. It increased cellular antioxidant defense, particularly by increasing GPx, glutathione, GR, and catalase levels, preserved normal hepatic and renal histological architecture.

Conclusion: It could be concluded that AEMK has significant radical scavenging activity and can mop up Al-induced toxicity, suggesting hepatoprotective and nephroprotective potential.

Keywords: Hepatoprotective, Nephroprotective, Aluminum chloride, Murraya koenigii, Aqueous extract.

(C) 2020 The Authors. Published by Innovare Academic Sciences Pvt Ltd. This is an open access article under the CC BY license (http://creativecommons. org/licenses/by/4. 0/) DOI: http://dx.doi.org/10.22159/ajpcr.2020.v13i6.37383

\section{INTRODUCTION}

Aluminum [1] can accumulate in many tissues, such as kidney, liver, heart, blood, bone, and brain [2]. The toxic effect of aluminum was observed to be mediated by reactive oxygen species generation resulting in the oxidative deterioration of cellular lipids, proteins, and DNA and also induces changes in the activities of tissue antioxidant enzymes [3] altered gene expression and apoptosis [4]. The induced oxidative stress by aluminum and its salts is responsible for hepatotoxicity [5], nephrotoxicity [6], cardiac toxicity, and reproductive toxicity [7] and also neurodegenerative disease and Alzheimer like neurofibrillary tangle formation [8]. Hence, the external supply of antioxidants is important to suppress caspase activation and for the defense against the deleterious effects of oxidative stress [9]. Several chelating agents and antagonists are established to reduce metal toxicity; some of them are burned with undesirable side effects. Due to the intrinsic limitations and variability of the efficacy of heavy metal chelating agents, metal intoxication therapy is looking for the development of new therapeutic agents with different actions, especially from phytochemicals. Natural antioxidants, which alleviate the oxidative stress or induce the cellular antioxidant, can able to treat against Al poisoning. Murraya koenigii (MK) is known as curry leaf which is belonging to family Rutaceae. Numerous active constituents of MK are found to be potent antioxidant. It possesses numerous pharmacological effects such as anti-inflammatory, anticancer, memory improvement, and anti-obesity activities. The present research was carried out to investigate the possible nephroprotective and cholesterol-lowering activity of MK against aluminum chloride $\left(\mathrm{AlCl}_{3}\right)$-induced intoxication in terms of oxidative stress, biochemical, and histological aspects. The novelty of present research to avoid shortcomings of conventional dosage forms activity on animal study, but the present AEMK leaves are mostly effective against $\mathrm{AlCl}_{3}$-induced oxidative stress in rats.

\section{MATERIALS AND METHODS}

\section{Plant material}

The fresh leaves of MK were obtained from the outskirts of Maisammaguda situated in the state of Telangana (India). The plant material was identified and authenticated by Dr. H. Ramakrishna, H.O.D, Department of Botany, Osmania University, Telangana, India.

\section{Chemicals}

All chemicals, used in this study, were of analytical grade. $\mathrm{AlCl}_{3}$ was purchased from Sigma Chemical Company, St. Louis, Missouri, USA. Aqueous extract of MK was prepared using the maceration process.

\section{Animals}

Ethical approval of this experimental study was obtained from the Institutional Animal Ethical Committee of Malla Reddy College of Pharmacy, Hyderabad, with Reg. No 1217/P0/Re/S/08/CPCSEA. Thirty-six albino rats with average body weight (b.w) from 150 to $250 \mathrm{~g}$ were utilized in this study. They were procured from Teena labs, Plot no 41, SV cooperative industrial estates, Bachupally (V), Quthbullapur. The rats were housed in polypropylene cages and maintained under standard conditions (12 h light and dark cycles at $25 \pm 3^{\circ} \mathrm{C}$ and $35-60 \%$ humidity)

\section{Experimental design}

Group I (control) and Group II administered with distilled water and $\mathrm{AlCl}_{3}(40 \mathrm{mg} / \mathrm{kg}$ b.w, oral), respectively. Group III rats were treated with standard Vitamin E (100 mg/kg b.w, p.o) and $\mathrm{AlCl}_{3} 40 \mathrm{mg} / \mathrm{kg}$ b.w, oral). Group IV, V, and VI received aqueous extract of leaves of Murraya koenigii (AEMK) (100 mg/kg b.w, p.o, $200 \mathrm{mg} / \mathrm{kg} \mathrm{b.w,} \mathrm{p.o,} 400 \mathrm{mg} / \mathrm{kg}$ b.w, p.o), respectively, for a period of 35 days. 
The animals were sacrificed on the $35^{\text {th }}$ day by $\mathrm{CO}_{2}$ inhalation through Euthanasia Chamber and blood was immediately collected by carotid bleeding method followed by centrifugation. Livers and kidneys were dissected rapidly, a part of these tissues were minced and then homogenized with phosphate buffer using tissue homogenizer. The resultant supernatant was removed and stored at $-80^{\circ} \mathrm{C}$ until used for antioxidant enzyme activities and lipid peroxidation (malondialdehyde [MDA]) assays.

\section{Biochemical assessment}

Reitman and Frankel [10] method was used to get serum alanine aminotransferase (ALT) and aspartate aminotransferase (AST). Belfeld [11] method was used to get serum alkaline phosphatase (ALP). Total bilirubin was determined calorimetrically according to Schmidt and Eisenburg method. Serum urea and creatinine [12] were determined according to previous reports. Serum total cholesterol [13], triglycerides [14], high-density lipoprotein cholesterol, and low-density lipoprotein cholesterol were determined as previously described by Richmond and Fossati principle [15].

Biochemical estimation of markers of oxidative stress

Ellman method [16] was used to get glutathione (GSH) level, and enzymatic antioxidant catalase (CAT) activity was also assessed, according to Aebi et al. method [17]. Glutathione peroxidase was observed by Hafeman et al. method [18] with some modifications. MDA level was analyzed by estimation of the produced thiobarbituric acid

Table 1: Effect of aqueous extract of MK leaves on body weight in $\mathrm{AlCl}_{3}$-induced oxidative stress in rats

\begin{tabular}{lll}
\hline Groups & Initial weight $(\mathrm{g}) \pm$ SEM & $\begin{array}{l}\text { Final weight after treatment } \\
\text { (g) } \pm \text { SEM }\end{array}$ \\
\hline Group I & $197 \pm 4.47$ & $199 \pm 1.32$ \\
Group II & $226 \pm 4.41$ & $195 \pm 4.49^{\wedge}$ \\
Group III & $239 \pm 3.99$ & $228 \pm 5.89^{\#}$ \\
Group IV & $183 \pm 4.54$ & $170 \pm 7.23^{*}$ \\
Group V & $185 \pm 3.42$ & $172 \pm 4.22^{* *}$ \\
Group VI & $188 \pm 6.94$ & $175 \pm 5.91^{* * *}$ \\
\hline
\end{tabular}

NB values are expressed as mean \pm SEM, $n=6,{ }^{\wedge} p<0.01$ when compared to control group, ${ }^{\#} \mathrm{p}<0.001$ when compared with $\mathrm{AlCl}_{3}$-treated group, ${ }^{*} \mathrm{p}<0.005$

${ }^{* *} \mathrm{p}<0.0001$ when compared with $\mathrm{AlCl}_{3}$-treated group

Table 2: Effect of aqueous extract of MK leaves on organ weight in $\mathrm{AlCl}_{3}$-induced oxidative stress in rats

\begin{tabular}{lll}
\hline Groups & Kidney $(\mathrm{g}) \pm$ SEM & Liver $(\mathrm{g}) \pm$ SEM \\
\hline Group I & $1.31 \pm 0.06$ & $8.00 \pm 1.08$ \\
Group II & $1.96 \pm 0.08^{\wedge}$ & $8.51 \pm 0.18^{\wedge}$ \\
Group III & $1.86 \pm 0.04^{\#}$ & $7.84 \pm 0.16^{\#}$ \\
Group IV & $1.89+0.05^{*}$ & $8.12 \pm 1.33^{*}$ \\
Group V & $1.64 \pm 0.07^{* *}$ & $7.78 \pm 1.40^{* *}$ \\
Group VI & $1.52 \pm 0.06^{* * *}$ & $7.11 \pm 1.28^{* * *}$ \\
\hline
\end{tabular}

NB values are expressed as mean \pm SEM, $n=6, \wedge p<0.01$ when compared to control group, ${ }^{\#} \mathrm{p}<0.001$ when compared with $\mathrm{AlCl}_{3}$-treated group, ${ }^{*} \mathrm{p}<0.005$,

$* * \mathrm{p}<0.0001$ when compared with $\mathrm{AlCl}_{3}$-treated group reactive substances by the method of Buege and Aust [19]. Glutathione reductase activity was measured according to previous reports [20].

\section{Histopathological study}

On completion of the regimen, animals [21] were sacrificed, the liver and kidney were dissected out and fixed in $10 \%$ buffered neutral formalin solution and further processed to obtain of paraffin blocks. Five-micron thick paraffin sections were prepared and routinely stained with hematoxylin and eosin and examined for the histopathological changes using the light microscope.

\section{Statistical analysis}

The results were analyzed [22-24] by one-way analysis of variances followed by Dunnett's test using the graph pad statistical software for comparison between different experimental groups. $p<0.001$ were considered statistically significant. The intergroup variation between various groups was conducted by GraphPad Prism software and t-test. Values are expressed as mean \pm SEM. ${ }^{\wedge} \mathrm{p}<0.01$ when compared to the control group, ${ }^{*} \mathrm{p}<0.001$ when compared with the $\mathrm{AlCl}_{3}$-treated group, and ${ }^{*} \mathrm{p}<0.005,{ }^{* *} \mathrm{p}<0.0001$ when compared with the $\mathrm{AlCl}_{3}$-treated group.

\section{RESULTS AND DISCUSSION}

The b.w. of rats from the toxin group was significantly $(\mathrm{p}<0.0001)$ decreased when compared with the normal control group. Treatment with extract of aqueous extract of $\mathrm{MK}$ before $\mathrm{AlCl}_{3}$ intoxication is reported (Table 1) dose-dependent protection.

It was observed that the weight of the kidney and liver of rats from the toxin group was significantly $(\mathrm{p}<0.0001)$ decreased when compared with the normal control group. Treatment with aqueous extract of MK before $\mathrm{AlCl}_{3}$ intoxication has shown dose-dependent protection (Table 2).

It was reported that oral administration of $\mathrm{AlCl}_{3}$ to Wistar albino rats for 35 days resulted in a significant increase $(\mathrm{p}<0.001)$ in serum activities of AST, ALT, ALP, and total bilirubin concentration. The levels of all these parameters showed significant improvement toward their normal levels when AEMK and Vitamin-E were concomitantly administered with $\mathrm{AlCl}_{3}$ was given in Table 3 .

It was observed that by oral administration of $\mathrm{AlCl}_{3}$ to Wistar albino rats for 35 days resulted in a significant increase $(p<0.001)$ in urea and creatinine level when compared with the other experimental groups. The cotreatment of rats with $\mathrm{AlCl}_{3}$ and Vitamin-E, AEMK for the same period improves kidney status and retained the aforementioned parameters toward the normal level when compared with the $\mathrm{AlCl}_{3}$ treated group is shown in Table 4.

Itwas observed that with $\mathrm{AlCl}_{3}$-treated group serum cholesterol, triglyceride, and low-density lipoprotein-cholesterol levels were significantly higher in the groups receiving $\mathrm{AlCl}_{3}$ alone compared to the standard- and extracttreated groups. There was also a significant decrease in the levels of highdensity lipoprotein-cholesterol in $\mathrm{AlCl}_{3}$ receiving group. The cotreatment of rats with $\mathrm{AlCl}_{3}$ and Vitamin-E, AEMK for the same period, retained the aforementioned parameters toward the normal level when compared with the $\mathrm{AlCl}_{3}$-treated group was given in Table 5 .

Table 3: Effect of aqueous extract of MK leaves in serum biochemical parameters for hepatoprotective activity in $\mathrm{AlCl}_{3}$-induced oxidative stress in rats

\begin{tabular}{|c|c|c|c|c|}
\hline Groups & SGOT $(U / L) \pm S E M$ & SGPT $(U / L) \pm S E M$ & $\operatorname{ALP}(U / L) \pm S E M$ & Bilirubin $(\mathrm{mg} / \mathrm{dl}) \pm \mathrm{SEM}$ \\
\hline Group I & $8.66 \pm 0.22$ & $10.35 \pm 0.22$ & $110.29 \pm 0.23$ & $0.20 \pm 0.04$ \\
\hline Group II & $19.35 \pm 0.22^{\wedge}$ & $22.35 \pm 0.22^{\wedge}$ & $274.58 \pm 0.17^{\wedge}$ & $1.62 \pm 0.17^{\wedge}$ \\
\hline Group III & $7.21 \pm 0.07^{\#}$ & $11.98 \pm 0.12^{\#}$ & $120.70 \pm 0.12^{\#}$ & $0.80 \pm 0.04^{\#}$ \\
\hline Group IV & $8.92 \pm 0.02 *$ & $10.52 \pm 0.16^{*}$ & $159.70 \pm 0.47^{*}$ & $1.25 \pm 0.09 *$ \\
\hline Group V & $8.47 \pm 0.09^{* *}$ & $8.75 \pm 0.09 * *$ & $146.30 \pm 0.19^{* *}$ & $1.05 \pm 0.09 * *$ \\
\hline Group VI & $7.52 \pm 0.09 * * *$ & $5.65 \pm 0.17^{* * *}$ & $132.60 \pm 0.21 * * *$ & $0.82 \pm 0.06^{* * *}$ \\
\hline
\end{tabular}

NB values are expressed as mean \pm SEM, $n=6,{ }^{\wedge} \mathrm{p}<0.01$ when compared to control group, ${ }^{\#} \mathrm{p}<0.001$ when compared with $\mathrm{AlCl}_{3}$-treated group, ${ }^{*} \mathrm{p}<0.005$, ${ }^{* *} \mathrm{p}<0.0001$ when compared with $\mathrm{AlCl}_{3}$-treated group 
$\mathrm{AlCl}_{3}$ treatment resulted in a case of oxidative stress represented by decreased level of GPx, GR, CAT, and lowered GSH contents with the elevated MDA level (an indicator of lipid peroxidation) in liver and kidney tissues homogenates. It is reported in Tables 6 and 7.

\section{Histopathological results}

Rats receiving $\mathrm{AlCl}_{3}$ showed distorted portal area and edema, bleeding in the portal vein, fibrosis around portal area, and vacuolar degeneration of

Table 4: Effect of aqueous extract of MK leaves in serum biochemical parameters for nephroprotective activity in $\mathrm{AlCl}_{3}$ induced oxidative stress in rats

\begin{tabular}{lll}
\hline Groups & Urea $(\mathbf{m g} / \mathbf{d l}) \pm$ SEM & Creatinine $(\mathbf{m g} / \mathbf{d l}) \pm$ SEM \\
\hline Group I & $48.16 \pm 0.41$ & $1.22 \pm 0.16^{\wedge}$ \\
Group II & $70.99 \pm 0.40^{\wedge}$ & $3.00 \pm 0.08^{\wedge}$ \\
Group III & $55.09 \pm 0.31^{\#}$ & $1.02 \pm 0.006^{\#}$ \\
Group IV & $61.13 \pm 0.29^{*}$ & $2.175 \pm 0.11^{*}$ \\
Group V & $56.63 \pm 0.22^{* *}$ & $2.104 \pm 0.10^{* *}$ \\
Group VI & $52.33 \pm 0.45^{* * *}$ & $1.175 \pm 0.11^{* * *}$ \\
\hline
\end{tabular}

NB values are expressed as mean $\pm S E M, n=6, \wedge p<0.01$ when compared to control group, ${ }^{\#} \mathrm{p}<0.001$ when compared with $\mathrm{AlCl}_{3}$-treated group, ${ }^{*} \mathrm{p}<0.005$, ${ }^{* *} \mathrm{p}<0.0001$ when compared with $\mathrm{AlCl}_{3}$-treated group hepatocytes. The study of histological structures of $\mathrm{AlCl}_{3}+\mathrm{Vit}-\mathrm{E}$ showed normal hepatocytes lining of central vein, hepatocytes with normal nucleus and less atrophy of hepatocytes nucleus. The histomorphology of rats treated with $\mathrm{AlCl}_{3}$ then AEMK $(100 \mathrm{mg} / \mathrm{kg})$ showed bleeding in the portal vein and atrophy of some hepatocytes. The histomorphology of rats treated with $\mathrm{AlCl}_{3}$ then AEMK $(200 \mathrm{mg} / \mathrm{kg})$ showed a slight expansion of sinusoids and moderate atrophy. Rats receiving $\mathrm{AlCl}_{3}$ then AEMK $(400 \mathrm{mg} / \mathrm{kg}$ ) showed normal lining of the central vein and less atrophy (Fig. 1).

Histopathological changes in the kidney tissue were shown in Fig. 2. It was confirmed that in Group I control rats showed normal glomeruli with an intact bowman's capsule and proximal convoluted tubule, in Group II kidney sections of rats observed modest congestion of blood vessels, necrosis of the renal cells, degeneration of glomeruli, intrarenal arterial vessel showed modest thickening of the walls, and degree of tubule interstitial damage, in Group III of rats showed intact renal cortex, preserved cellularity of renal corpuscles, and intact renal tubules, in Group IV of rats showed degenerated glomeruli, and Group V rats showed moderate congestion in glomerular degeneration with tubule interstitial damage.

It was observed that aluminum can inhibit NADPH-generating enzymes such as NADP-isocitrate dehydrogenase and glucose

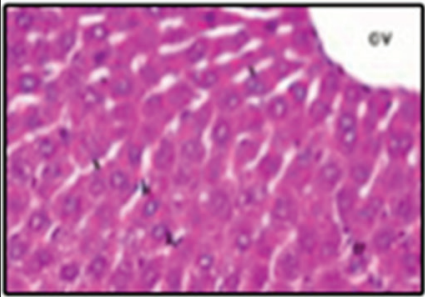

Group I

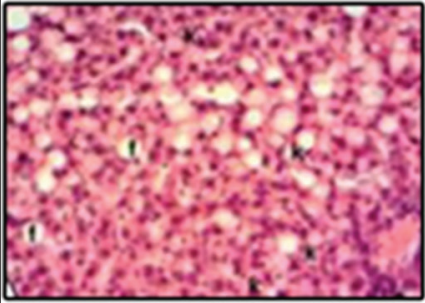

Group IV

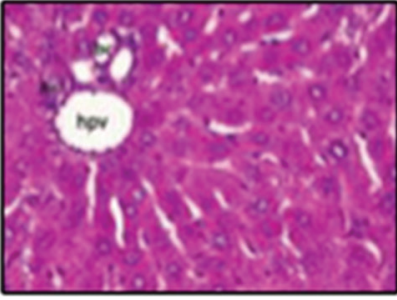

Group II

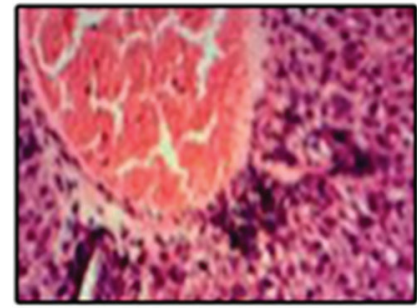

Group V

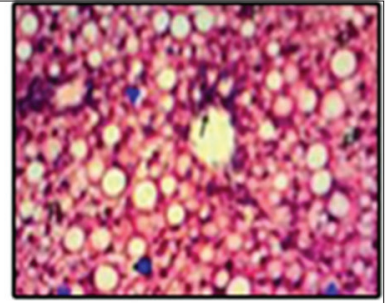

Group III

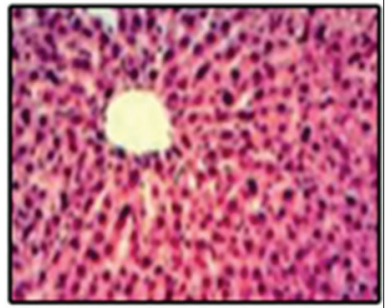

Group VI

Fig. 1: Histopathological changes in the liver tissue of experimental groups

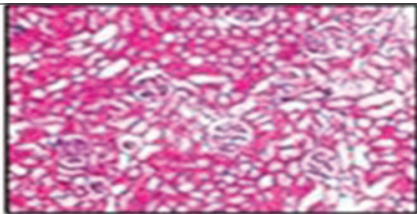

Group I

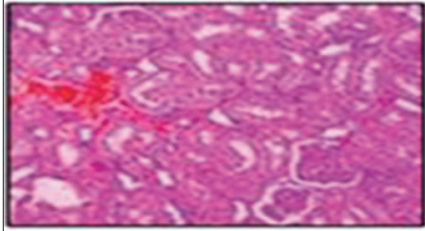

Group IV

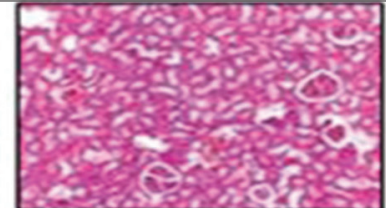

Group II

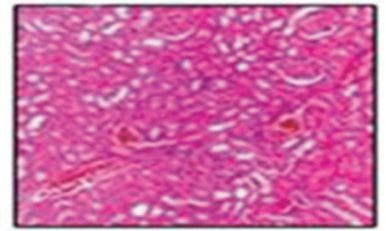

Group V

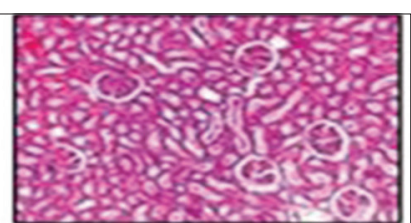

Group III

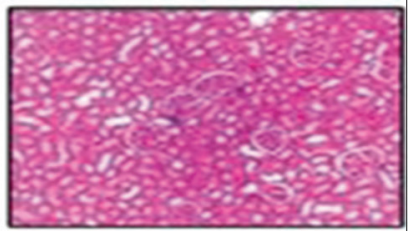

Group VI

Fig. 2: Histopathological changes in the kidney tissue of experimental groups 
Table 5: Effect of aqueous extract of $\mathrm{MK}$ leaves in serum biochemical parameters for lipid-lowering activity in $\mathrm{AlCl}_{3}$-induced oxidative stress in rats

\begin{tabular}{|c|c|c|c|c|}
\hline Groups & HDL (mg/dl) \pm SEM & LDL (mg/dl) \pm SEM & Total cholesterol (mg/dl) $\pm S E M$ & Triglycerides $(\mathrm{mg} / \mathrm{dl}) \pm \mathrm{SEM}$ \\
\hline Group I & $31.25 \pm 1.11$ & $45.06 \pm 1.15$ & $97.25 \pm 1.49$ & $104.68 \pm 0.5$ \\
\hline Group II & $16.75 \pm 1.11^{\wedge}$ & $101.97 \pm 1.12^{\wedge}$ & $144.50 \pm 2.94^{\wedge}$ & $128.87 \pm 0.08^{\wedge}$ \\
\hline Group III & $27.00 \pm 0.91^{\#}$ & $62.26 \pm 0.18^{\#}$ & $105 \pm 2.10^{\#}$ & $78.66 \pm 1.1^{\#}$ \\
\hline Group IV & $14.25 \pm 0.85^{*}$ & $86.85 \pm 1.05^{*}$ & $117.50 \pm 0.65^{*}$ & $82.83 \pm 1.05^{*}$ \\
\hline Group V & $15.50 \pm 0.65^{* *}$ & $81.51 \pm 1.15^{* *}$ & $114.25 \pm 0.48^{* *}$ & $86.19 \pm 1.1^{* *}$ \\
\hline Group VI & $22.09 \pm 0.86^{* * *}$ & $71.60 \pm 1.12^{* * *}$ & $111.00 \pm 0.41^{* * *}$ & $87.51 \pm 1.1^{* * *}$ \\
\hline
\end{tabular}

NB values are expressed as mean \pm SEM, $n=6,{ }^{\wedge} \mathrm{p}<0.01$ when compared to the control group, ${ }^{*} \mathrm{p}<0.001$ when compared with $\mathrm{AlCl}{ }_{3}$-treated group, ${ }^{*} \mathrm{p}<0.005,{ }^{* *} \mathrm{p}<0.0001$ when compared with $\mathrm{AlCl}_{3}$-treated group. LDL-C: Low-density lipoprotein-cholesterol, HDL-C: High-density lipoprotein-cholesterol

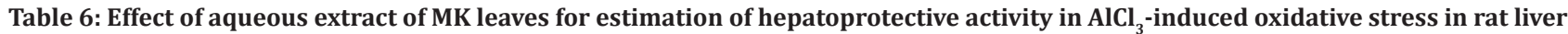

\begin{tabular}{|c|c|c|c|c|c|}
\hline Groups & MDA (nm/g) $\pm S E M$ & GSH $(\mu \mathrm{g} / \mathrm{ml}) \pm S E M$ & Catalase $(\mathrm{K} / \mathrm{min}) \pm \mathrm{SEM}$ & $\operatorname{GR}(\mu / \mathrm{ml}) \pm S E M$ & $\mathrm{GP}_{\mathrm{X}}(\mathrm{nm} / \mathrm{g}) \pm \mathrm{SEM}$ \\
\hline Group I & $155.78 \pm 0.84$ & $27.5 \pm 0.5$ & $21 \pm 1.0$ & $20.83 \pm 0.60$ & $38.33 \pm 0.5$ \\
\hline Group II & $429.12 \pm 1.4^{\wedge}$ & $13.5 \pm 0.5^{\wedge}$ & $11.5 \pm 0.5^{\wedge}$ & $11.33 \pm 0.49^{\wedge}$ & $21.16 \pm 0.47^{\wedge}$ \\
\hline Group III & $155.05 \pm 1.08^{\#}$ & $35.7 \pm 0.5^{\#}$ & $18.91 \pm 0.5^{\#}$ & $24.66 \pm 0.92^{\#}$ & $34.33 \pm 0.55^{\#}$ \\
\hline Group IV & $166.16 \pm 1.48^{*}$ & $27.5 \pm 0.5^{*}$ & $14.5 \pm 0.5^{*}$ & $16.5 \pm 0.42^{*}$ & $26 \pm 0.36^{*}$ \\
\hline Group V & $160.31 \pm 0.84^{* *}$ & $29.5 \pm 0.5^{* *}$ & $15.5 \pm 1.0 * *$ & $18 \pm 0.5^{* *}$ & $28.33 \pm 0.33^{* *}$ \\
\hline Group VI & $152.46 \pm 0.93^{* * *}$ & $32.5 \pm 0.5^{* * *}$ & $17.5 \pm 0.5^{* * *}$ & $21.5 \pm 0.42^{* * *}$ & $32.33 \pm 0.5^{* * *}$ \\
\hline
\end{tabular}

NB values are expressed as mean \pm SEM, $n=6,{ }^{\wedge} \mathrm{p}<0.01$ when compared to control group, ${ }^{*} \mathrm{p}<0.001$ when compared with $\mathrm{AlCl}_{3}$-treated group, ${ }^{*} \mathrm{p}<0.005,{ }^{* *} \mathrm{p}<0.0001$ when compared with $\mathrm{AlCl}_{3}$-treated group

Table 7: Effect of aqueous extract of MK leaves for estimation of nephroprotective activity in $\mathrm{AlCl}_{3}$-induced oxidative stress in rat kidney

\begin{tabular}{|c|c|c|c|c|c|}
\hline Groups & MDA (nm/g) $\pm S E M$ & GSH $(\mu \mathrm{g} / \mathrm{ml}) \pm S E M$ & Catalase $(\mathrm{K} / \mathrm{min}) \pm \mathrm{SEM}$ & $\mathrm{GR}(\mu / \mathrm{ml}) \pm \mathrm{SEM}$ & $\mathrm{GP}_{\mathrm{X}}(\mathrm{nm} / \mathrm{g}) \pm \mathrm{SEM}$ \\
\hline Group I & $152.78 \pm 0.84$ & $24.5 \pm 0.5$ & $21.32 \pm 1.0$ & $20.33 \pm 0.60$ & $36.33 \pm 0.5$ \\
\hline Group II & $422.12 \pm 1.4^{\wedge}$ & $12.5 \pm 0.5^{\wedge}$ & $10.5 \pm 0.5^{\wedge}$ & $11.83 \pm 0.49^{\wedge}$ & $22.16 \pm 0.47^{\wedge}$ \\
\hline Group III & $148.05 \pm 1.08^{\#}$ & $36.7 \pm 0.5^{\#}$ & $18.71 \pm 0.5^{\#}$ & $22.88 \pm 0.92^{\#}$ & $32.33 \pm 0.55^{\#}$ \\
\hline Group IV & $168.16 \pm 1.48^{*}$ & $25.5 \pm 0.5^{*}$ & $13.5 \pm 0.5^{*}$ & $14.5 \pm 0.42^{*}$ & $23 \pm 0.36^{*}$ \\
\hline Group V & $158.31 \pm 0.84^{* *}$ & $27.5 \pm 0.5^{* *}$ & $14.5 \pm 1.0^{* *}$ & $16.2 \pm 0.5^{* *}$ & $25.33 \pm 0.33^{* *}$ \\
\hline Group VI & $150.46 \pm 0.93^{* * *}$ & $30.5 \pm 0.5^{* * *}$ & $15.5 \pm 0.5^{* * *}$ & $19.53 \pm 0.42^{* * *}$ & $29.33 \pm 0.5^{* * *}$ \\
\hline
\end{tabular}

NB values are expressed as mean $\pm \mathrm{SEM}, \mathrm{n}=6,{ }^{\wedge} \mathrm{p}<0.01$ when compared to control group, ${ }^{*} \mathrm{p}<0.001$ when compared with $\mathrm{AlCl}_{3}$-treated group, ${ }^{*} \mathrm{p}<0.005,{ }^{* *} \mathrm{p}<0.0001$ when compared with $\mathrm{AlCl}_{3}$-treated group

6-phosphate dehydrogenase. Since NADPH is shown to be a main factor for the GSH regeneration, the decreased GSH level could be also ascribed to the insufficient supply of NADPH. The higher intracellular aluminum concentration reduced protein synthesis of antioxidant enzymes and subsequently reduced their activities. Simultaneous administrations of $\mathrm{AEMK}$ with $\mathrm{AlCl}_{3}$ replenish the antioxidant enzyme activities near to normal with an increase in GPx activities, GR, CAT, and GSH level and diminish MDA level as a marker of LPO in liver and kidney when compared with $\mathrm{AlCl}_{3}$ treated rats. This is due to the aqueous extract of MK to reduce the accumulation of free radical generation during Al-induced lipid peroxidation. AEMK is able to inhibit the free radical generation, could further reduce the oxidative threat caused by aluminum, which could mitigate the consumption of endogenous enzymatic and non-enzymatic antioxidants and increased their levels and markedly reduces the hepatic and renal LPO. In the current study, it was observed that AEMK played an important role as an antioxidant, which includes free radical scavenging and metal-chelating property and thereby improved the detrimental state of liver and kidney cells which unraveled its use as a possible attenuating agent in aluminuminduced hepatotoxicity and nephrotoxicity. Hence, overall it was observed that AEMK administration markedly reduces the hepatic and renal toxicity in rats.

\section{CONCLUSION}

It showed that MK played an important role as an antioxidant, which includes free radical scavenging and metal-chelating property and thereby improved the detrimental state of liver and kidney cells which unraveled its use as a possible attenuating agent in aluminum-induced hepatotoxicity and nephrotoxicity.

\section{ACKNOWLEDGMENTS}

The authors are thankful to the management of Malla Reddy College of Pharmacy, for providing the required facilities to carry out the research work.

\section{AUTHORS' CONTRIBUTIONS}

CK Dhanapal and BVS Lakshmi planned and designed the whole work. B. Maheswari Reddy did the whole research work. It is a part of the research work Ph.D. thesis of B.M.R.

\section{CONFLICTS OF INTEREST}

The author declares that they have no conflicts of interest.

\section{AUTHORS' FUNDING}

There is no fund for research work.

\section{REFERENCES}

1. Inan-Eroglu E, Ayaz A. Is aluminum exposure a risk factor for neurological disorders. J Res Med Sci 2018;23:51.

2. Al-Kahtani AM, Abdel-Moneim MA, El-Sayed, MW. The influence of taurine pretreatment on aluminum chloride induced nephrotoxicity in Swiss albino mice. Histopathology 2014;29:45-55.

3. Farina M, Rotta LN, Soares FA. Jardim AF, Souza DO, Rocha JB. Hematological changes in rats chronically exposed to oral aluminum. Toxicology 2005;209:29-37

4. Stohs SJ, Bagchi D, Hassoun E, Bagchi M. Oxidative mechanisms in the toxicity of chromium and cadmium ions. J Environ Pathol Toxicol Oncol 2000;20:77-88.

5. Mailloux RJ, Lemire J, Appama VD. Hepatic response to aluminum 
toxicity: Dyslipidemia and liver disease. Exp Cell Res 2011;317:2231-8.

6. Nan Z, Ping L, Lina H. Protection of aluminum chelating agent against cardiac toxicity in rats exposed to aluminum chloride. J Shandong Univ 2009;4:125-7.

7. Al-Hashem F. Camel's milk protects against aluminum chlorideinduced toxicity in the liver and kidney of white albino rats. Am J Biochem Biotechnol 2009;5:98-108.

8. Nehru B, Anand P. Oxidative damage following chronic aluminium exposure in adult and pup rat brains. J Trace Elem Med Biol 2005;19:203-8.

9. Schulze-Bergkamen H, Schuchmann M, Fleischer B, Galle PR. The role of apoptosis versus oncotic necrosis in liver injury: Facts or faith? J Hepatol 2006;44:984

10. Lippi U, Guidi G. A new colorimetric ultramicromethod for serum glutamic-oxalacetic and glutamic-pyruvic transaminase determination. Clin Chim Acta 1970;28:431-7.

11. Belfeld A, Goldberg D. Revised assay for serum phenyl phosphatase activity using 4- amino-antipyrine. Enzyme 1971;12:561-73.

12. Schmidt M, Eisenburg J. Serum bilirubin determination in newborn infants. A new micromethod for the determination of serum of plasma bilirubin in newborn infants. Fortschr Med 1975;93:1461-6.

13. Patton CJ, Crouch SR. Determination of urea (urease-modified Berthelot reaction). Anal Chem 1977;49:464-9.

14. Bonsens KE, Taussky S. Determination of serum creatinine. J Chem 1984;27:648-60
15. Richmond W. Cholesterol enzymatic colorimetric test chop PAP method of estimation of total cholesterol in serum. Clin Chem 1973;191:1350.

16. Fossati P, Prencipe L. Serum triglycerides determined colorimetrically with an enzyme that produces hydrogen peroxide. Clin Chem 1982;28:2077-80.

17. Ellman GL. Tissue sulfhydryl groups. Arch Biochem Biophys 1959; 17:214-26.

18. Aebi H. Catalase in vitro. Methods Enzymol 1984;105:121-6.

19. Rotruck JT, Pope AL, Ganther HE, Swanson AB, Hafeman DG, Hoekstra WG. Selenium: Biochemical role as a component of glutathione peroxidase. Science 1973;179:588-90

20. Buege JA, Aust SD. Microsomal lipid peroxidation. Methods Enzymol 1978;52:302-10.

21. Newairy AS, Salama AF, Hussien HM, Yousef MI. Propolis alleviates aluminum-induced lipid peroxidation and biochemical parameters in male rats. Food Chem Toxicol 2009;47:1093-8.

22. Mangood SA, Kamal AM, Haggag AM. Propolis protection from toxicity caused by aluminum chloride in male rats. Appl Radiat Isot 2012;44:623-33

23. Beidokhti MN, Prakash HS Antioxidant and anti-inflammatory potential of selected medicinal plants of Lamiaceae family. Int J Pharm Pharm Sci 2013;5 Suppl 1:100-4.

24. Iswariya S, Uma TS. Evaluation of in vitro anti-inflammatory and antimicrobial activity of aqueous and methanolic seed extracts of Citrullus lanatus. Int J Pharm Pharm Sci 2017;9:29-33. 